\title{
Study on the Image of Government in Crisis
}

\author{
Jinhua Jiang \\ Graduate School of public administration \\ Tianjin Commercial University \\ Tianjin, China
}

\begin{abstract}
The whole process of shaping the image of the government, in fact, is to break through the barriers of the government, the establishment of political self-confidence, the hearts of the people in the process of political practice, but also with foreign hostile forces game process. how to grasp the opportunity in the event of an emergency for the government will co-ordinate resources, as an issue of "national imagination" to the international exhibition show, as the image of the government or the start of re creation.
\end{abstract}

Keywords—unexpected events; government image; policy

\section{INTRODUCTION}

The government image is the overall performance and effect of the government, that is, the behavior of the political organization system and the public's assessment of the stability and fairness of the government's actions. The composition of the government image is also composed of three elements in the traditional sense. That is, the ruling idea of the government, the ruling behavior of the government and the direct feeling of the public.

\section{THE CHARACTERISTICS OF CRISIS EVENTS AND PARTICIPATION FORCES ANALYSIS}

From the beginning of the crisis - Development - - - the outbreak of fermentation calm the whole process is full of uncertainty, it is for emergency early warning mechanism government put forward new demands, namely in the random events along the direction of the development of the situation out of control, make the government response.

\section{A. The Crisis Has a Strong Foreign}

Rosen Hauer believes that the crisis is the basic value of a social system or a serious threat to the framework of standards, and because of the timing and uncertainty to make key decisions. 1 Norman R. Augustin. Crisis management [M]. Beijing: Renmin University of China press, 2001: 4

It is a serious threat to the national security of our country, and the root cause of the crisis is the foreign affairs, which is the key point of the intervention. Such as "2014 Hongkong occupy Central Incident" has fully exposed some countries want to use small have an ulterior motive China organization youth group "umbrella revolution". Enterprise

\footnotetext{
${ }^{1}$ Norman R. Augustin. Crisis management [M]. Beijing: Renmin University of China press, 2001: 4
}

profit risk, capital input and the consciousness revolution channels to negate the leadership of the Communist Party of China power and economic status of the engine. Although this kind of public emergencies involving foreign organizations is not common, it does not rule out the beginning of a new type of emergency. In addition, the event also has the most common features of regional and temporal.

\section{B. The Parties Involved in the Crisis in the Degree of Clear Comparative Standard}

In the crisis, because of its occurrence in the public domain, due to many uncertainties, it will be a serious threat to public interests and public security. 2 "In addition to the government as participating subject must be involved in the outside crisis public relations, media power, the outbreak of the main force, the credibility of the government and government reputation and non realistic participation, will be more or less about the public emergencies result. If the public emergency is a mixed there for the government, then the government and the media as the balance of speech communication, plays a role of "navigation" to a certain extent.

\section{THE GOVERNMENT FACES CHALLENGES IN THE CRISIS}

\section{A. The Government Speculative Psychology}

The government's existence is always dramatic. On the one hand, both for the people want a convenient, efficient government to pay for the ideal, on the other hand, but also to face up to their own can not play a more satisfactory role in the normalization of emergencies and apologize. According to the communication and journalism, every seven people, our information occurs an interesting cycle. In the face of today's increasingly well-developed information channel and complex relationship network, the dissemination of information has been achieved towards into the late "mode, so to a certain extent, high efficiency, fast reaction has become the ideal government in the eyes of the masses due to the mode, once the heart of appeal could not be satisfied, will have a very strong sense of difference and if this sense of difference cannot be met in a short period of time, the government's image among the masses will be greatly

\footnotetext{
${ }^{2}$ Zhu Xiaowen. Public relations of government under the perspective of public crisis $[\mathrm{J}]$. Journal of Zhongnan University of Economics and Law, 2007 (4): 94
} 
reduced, even to the extreme opposite way. However, the truth is that when emergency comes, in the "government evil", the government will actively choose to avoid or minimize the risk, in order to shape the image of the government and protect the government image in the risk of attack.

\section{B. Rescue Way Closed}

The unity and closeness of the government in the way of rescue is not only conducive to the settlement of the incident as soon as possible, but for the image of the government, even though it is very destructive. In the accident of 2008 723 EMU in Wenzhou, people gather the vision of the Chinese government's ability to respond to public emergencies. Preliminary analysis about the secretive, wrong government estimates the factors of casualties and the extent of casualties, both for the entire rescue process or the failure process of public relations crisis foreshadowed. Today, both the D301 and D3115 collision accidents caused by sudden or lightning caused tragedy seems to never arouse people's interest, but the government in the event of an emergency or as less as has put the whole country impressive. On the one hand is the authority of the disaster reason inference is not clear, not published by the public, cause people to doubt the new evidence difficult, on the other hand many times before the overthrow of the conclusion, makes the government to the public when positive interpretation of accident treatment, is not acceptable to the masses.

\section{Emergency Mechanism Is Not Complete}

Crisis emergency mechanism can be said to be a compulsory course for each government. This is not only related to the government's economic development, people's livelihood, but also related to the maintenance of the "government image". The establishment of emergency response mechanism is also the result of specific analysis of specific issues in the actual situation. The Chinese government in the establishment of early warning mechanism, compared with the developed countries there is a gap. For example, the process of information disclosure program and institutionalization, there is no set of open and applicable methods. "People's politics" refers to the government in the daily political activities, the government will be the public value of the government is the tendency of the public value of the country and the country to export. And this process is called the heart of the political process.

\section{THE GOVERnMENT'S POLICY FORMULATION IN THE CRISIS}

\section{A. Learn from Foreign Experience and Self Innovation}

Emergencies are both opportunities and challenges. Therefore, to take the initiative to intervene in the face of the unexpected events have occurred in a more passive way to be successful. Treatment of internationally acclaimed "Chile mine", it is better to show us how the developing countries take active mode of operation will be a "crisis rescue war" change the cost of the country's "national image show". First of all, the government of Chile will not be blocked to mine as a national scandal, but make it as an opportunity to promote the new image of chile. Secondly, the entire rescue process "Chile mine" including the government rescue strategy are open and transparent, which avoids the public suspicion psychology and media speculation and malicious hostile countries, won a good reputation in domestic and international. 3

\section{B. Improve the Information Disclosure and Accountability System}

Emergency information disclosure system in China is still in its infancy, in addition to the "People's Republic of China government information disclosure regulations" was first published in January 17, 2007 began to implement, the current system of information disclosure of emergencies and to establish and improve the work is only in its infancy. The first legislation to explore is the city of Shanghai including emergency accountability system: emergency accountability should be in accordance with all things to people, things to do, unavoidably, accountability processing chain principle. In the face of more and more transparent and open information channels, we no longer have to cover up the negative information of the capital, but need to have the courage to face the bad even worse results. A country, a nation only has the face of setbacks and uncompromising spirit, in order to maintain the image of the country, set up the national self-confidence. Let unexpected events become a rare opportunity to maintain the image of the country.

\section{CONCLUSION}

Dealing with the crisis consequences to the satisfaction of the masses directly related to establish a good image of the country and the satisfaction of the masses and the government in the emergency situation of rewards and punishments to the relevant responsible person have the most direct contact. 4

Therefore, it is very important for the establishment and development of a country's image that the decisive and feasibility of the emergency policy making. So the government should pay attention to the flexibility and insist on the principle when making the policy.

\section{REFERENCES}

[1] Norman R. Crisis management [M]. Beijing: Renmin University of China press, 2001: 4 (in Chinese)

[2] Zhu Xiaowen. Government public relations from the perspective of public crisis $[\mathrm{J}]$. Journal of Zhongnan University of Economics and Law, 2007 (4): 94

[3] in early winter. Mine in Chile: a national salvation EB /OL. (2010 10 - 13) $2011-01-03-10 . \mathrm{Http}: / /$ www.ycwb.com/e Paper/xkb/html/2010/18 / content_947322.htm.

[4] Wang Jiarui. The image of the government crisis PR in the shape of J. Journal of Qilu, 2009 (3)

\footnotetext{
${ }^{3}$ Early winter. Mine in Chile: a national salvation EB /OL. (2010 - 10 - 13) 2011 - 01 - 03 - 10.Http: / / www.ycwb.com/e Paper/xkb/html/2010 /18 / content_947322.htm.

${ }^{4}$ Wang Jiarui. The image of the government crisis PR in the shape of J. Journal of Qilu, 2009 (3).
} 